\title{
PENGEMBANGAN POSTER INTERAKTIF BERBASIS ANDROID PADA MUATAN IPA KELAS IV SEKOLAH DASAR
}

\author{
Fatimah Az' Zahra ${ }^{1}$, Tunjungsari Sekaringtyas ${ }^{2}$, Uswatun Hasanah ${ }^{3}$ \\ Fakultas Ilmu Pendidikan, Universitas Negeri Jakarta \\ e-mail: akunjaraya@gmail.com
}

\begin{abstract}
ABSTRAK
Penelitian ini bertujuan untuk menghasilkan poster interaktif berbasis android sebagai media pembelajaran pada muatan IPA di kelas IV sekolah dasar. Jenis penelitian yaitu Research and Development (R\&D) dengan model penelitian ADDIE. Tahapan pada penelitian ini terdiri dari analisis, desain, pengembangan, implementasi, dan evaluasi. Subjek pada penelitian ini meliputi tiga orang validator ahli, yaitu ahli media, ahli materi, dan ahli bahasa, serta peserta didik kelas IV sekolah dasar berjumlah 3 orang untuk evaluasi satu lawan satu dan 5 orang untuk evaluasi kelompok kecil. Hasil validasi menunjukkan poster interaktif berbasis android dinyatakan valid dengan persentase $97 \%$ oleh ahli media, $91,66 \%$ oleh ahli materi, dan $90 \%$ oleh ahli bahasa. Berdasarkan hasil rekapitulasi penilaian ahli, kualitas poster interaktif berbasis android dapat dikategorikan "Sangat Baik". Adapun hasil penilaian rata-rata dari uji coba satu lawan satu menunjukkan persentase sebesar $100 \%$ dan persentase sebesar $97,5 \%$ dari uji coba kelompok kecil sehingga poster interaktif berbasis android dapat dikategorikan "Sangat Baik".
\end{abstract}

Kata Kunci: penelitian pengembangan, poster interaktif, android, IPA, sekolah dasar

\section{ABSTRACT}

This research aims to produce an android-based interactive poster as a medium of learning in natural science content in fourth grade elementary school. The type of research is Research and Development $(R \& D)$ with the ADDIE research model. The stages in this research consist of analysis, design, development, implementation, and evaluation. The subjects in this study included three validator experts, namely media experts, material experts, and linguists, as well as fourth grade elementary school students gathered 3 people for one-to-one evaluation and 5 people for small group evaluation. The results show that android-based interactive posters are declared valid with a percentage of $97 \%$ by media experts, $91.66 \%$ by material experts, and $90 \%$ by linguists. Based on the recapitulation of expert assessments, the quality of android-based interactive posters can be categorized as "Very Good". The average assessment results from the one-to-one evaluation showed a percentage of $100 \%$ and a percentage of $97.5 \%$ from the small group evaluation so that the Android-based interactive poster could be categorized as "Very Good".

Keywords: development research, interactive poster, android, natural science, elementary school 


\section{PENDAHULUAN}

Pandemi Covid-19 menyebabkan berbagai aktivitas massal terhenti, salah satu aktivitas massal yang terdampak pandemi ini adalah proses belajar mengajar di sekolah. Seluruh lembaga pendidikan diharuskan melakukan pembelajaran dari rumah atau yang lebih dikenal dengan istilah Pembelajaran Jarak Jauh (PJJ). Salah satu kebijakan PJJ berdasarkan Surat Edaran Kemdikbud No. 4 Tahun 2020 mengenai Pelaksanaan Pendidikan dalam Masa Darurat Coronavirus Disease (Covid-19) adalah PJJ untuk memberikan pengalaman belajar yang bermakna, tanpa terbebani tuntutan menuntaskan seluruh capaian kurikulum untuk kenaikan kelas maupun kelulusan (Mendikbud, 2020: 1). Memberikan pembelajaran yang bermakna untuk peserta didik memerlukan berbagai usaha dari semua pihak yang terlibat dalam aktivitas belajar, salah satunya adalah kreativitas guru dalam menggunakan berbagai media yang dapat menarik perhatian peserta didik.

Berdasarkan hasil studi pendahuluan yang dilakukan yaitu wawancara dan observasi, media pembelajaran yang sering digunakan guru SDN Menteng 03 saat pembelajaran adalah video pembelajaran dan powerpoint yang dikirim melalui whatsapp. Menggunakan media pembelajaran yang sama dalam aktivitas pembelajaran dapat menimbulkan kebosanan karena peserta didik hanya menyimak penjelasan guru sehingga dibutuhkan sebuah pengembangan media yang dapat meningkatkan daya tarik peserta didik. Salah satu muatan pelajaran di sekolah dasar yang membutuhkan pengembangan media yang menarik adalah Ilmu Pengetahuan Alam (IPA). IPA merupakan muatan pelajaran yang mempelajari teori dan konsep berkaitan dengan peristiwa-peristiwa di alam (Dewi \& Kristin, 2017). Pembelajaran ini harus sesuai dengan hakikat IPA, yaitu harus terjadinya prsoses sains melalui kegiatan pengamatan, percobaan, maupun bereksperimen secara aktif sehingga menimbulkan kesadaran peserta didik untuk menjaga dan memperbaiki gelaja-gejala alam yang terjadi (Sulthon, 2016: 39). Upaya yang dapat dilakukan untuk meningkatkan daya tarik peserta didik dan dapat melibatkan peserta didik dalam proses sains adalah dengan mengembangkan sebuah media interaktif.

Media interaktif adalah suatu sistem penyampaian pengajaran yang dapat memungkinkan interaksi peserta didik terhadap pembelajaran (Widjayanti et al., 2018: 102). Menggunakan media interaktif diharapkan dapat meningkatkan aktivitas peserta didik karena melibatkan berbagai indra untuk mengolah informasi sehingga pemahaman informasi yang tersimpan dalam ingatan peserta didik dapat bertahan lebih lama (Sinta, 2016: 20). Media pembelajaran yang dapat dikembangkan menjadi media interaktif adalah poster. Poster merupakan media komunikasi yang efektif untuk digunakan dalam menayangkan informasi dan pengetahuan secara sederhana namun komprehensif (Pribadi, 2017: 52).

Poster sudah sejak lama digunakan dalam aktivitas belajar. Hal ini sejalan dengan penelitian terdahulu yang sudah dilakukan oleh Amallia Prajna Paramitha dengan judul "Pengembangan Media Poster pada Pembelajaran IPA Materi Ciri-Ciri Lingkungan Sehat dan Lingkungan Tidak Sehat Siswa Kelas III SDN Lirboyo 2 Tahun Pelajaran 2017/2018" menunjukkan bahwa poster dapat menjadi media pembelajaran yang menarik dan efektif untuk meningkatkan persentase peserta didik yang tuntas dalam pembelajaran (Paramitha, 2018: 8). Selanjutnya penelitian yang dilakukan oleh Elis Lisma Aspahani, dkk dengan judul "Rancangan Media E-poster Berbasis Website Pada Pembelajaran IPA di Sekolah Dasar" menunjukkan bahwa poster dapat menjadi media pembelajaran yang menarik dan mudah 
untuk dipahami oleh peserta didik (Aspahani et al., 2020: 164). Berdasarkan penelitian sebelumnya, peneliti pun akan mengembangkan poster sebagai media pembelajaran yang lebih menarik. Poster yang dikembangkan oleh peneliti memiliki perbedaan dengan poster pada penelitian terdahulu, yaitu mengembangkan poster menjadi poster interaktif. Poster interaktif adalah media yang kuat dengan warna serta pesan dengan maksud untuk menangkap perhatian, membujuk, dan memotivasi orang yang dapat melakukan aksi saling hubungan dan saling aktif dengan pembaca (Kusuma Firdani \& Tri Hariastuti, 2019: 108).

Poster interaktif dapat digunakan untuk meningkatkan perhatian peserta didik pada pembelajaran. Hal ini sejalan dengan hasil dari penelitian yang dilakukan oleh Dale and Kline bahwa poster interaktif merupakan media yang efektif untuk menarik perhatian, berkomunikasi, dan bertukar informasi dengan pengguna (Dale \& Kline, 2017: 243). Adapun penelitian pengembangan poster interaktif yang sudah dilakukan sebelumnya menunjukkan bahwa poster interaktif dapat meningkatkan antusias dari peserta didik (Kusuma Firdani \& Tri Hariastuti, 2019: 110). Hal ini sejalan dengan tujuan peneliti yang ingin mengembangkan poster interaktif sebagai inovasi media pembelajaran yang dapat meningkatkan daya tarik peserta didik. Adapun pengembangan yang dilakukan oleh peneliti adalah mengembangkan poster interaktif menjadi berbasis android.

Android menyediakan plattform terbuka bagi para pengembang untuk menciptakan aplikasi (Tahel \& Ginting, 2019: 115) sehingga penelitian ini akan menghasilkan sebuah poster interaktif dalam format aplikasi. Aplikasi yang digunakan untuk mengembangkan poster ini adalah Android Studio. Android Studio merupakan lingkungan pengembang perangkat lunak terpadu untuk mengembangkan aplikasi android (Herlina \& KH, 2019: 4). Poster ini dirancang dengan memuat materi IPA tentang pentingnya upaya pelestarian dan keseimbangan sumber daya alam yang ditampilkan melalui animasi dengan berbagai fitur interaktif. Fitur interaktif dapat menampilkan video materi dan kuis yang dapat menguji kemampuan peserta didik dalam memahami materi tersebut. Pengembangan poster interaktif berbasis android dalam muatan IPA ini perlu dilakukan. Khususnya pada sebagai usaha dalam memberikan inovasi media pembelajaran yang menarik untuk meningkatkan aktivitas belajar peserta didik di sekolah dasar.

\section{METODE}

Metode penelitian yang digunakan adalah penelitian pengembangan atau Research and Development (R\&D). Jenis penelitian ini bertujuan untuk mengembangkan pengetahuan sehingga menghasilkan suatu produk baru yang lebih inovatif (Riyanto \& Hatmawan, 2020: 3). Hal ini sejalan dengan pengertian R\&D dari Sugiyono bahwa penelitian pengembangan atau Research and Development (R\&D) adalah metode penelitian yang menghasilkan suatu produk tertentu dan produk tersebut akan diuji keefektifannya (Sugiyono, 2018: 297).

Model pengembangan yang digunakan dalam penelitian pengembangan ini adalah ADDIE yang merupakan singkatan dari Analyze, Design, Development, Implementation, and, Evaluation. Model ADDIE dikembangkan oleh Dick and Carry (1996) untuk merancang sistem pembelajaran (Rayanto \& Sugianti, 2020: 91). Secara visual, tahapan model ADDIE dapat dilihat pada bagan berikut (Budiarta, 2016: 4): 


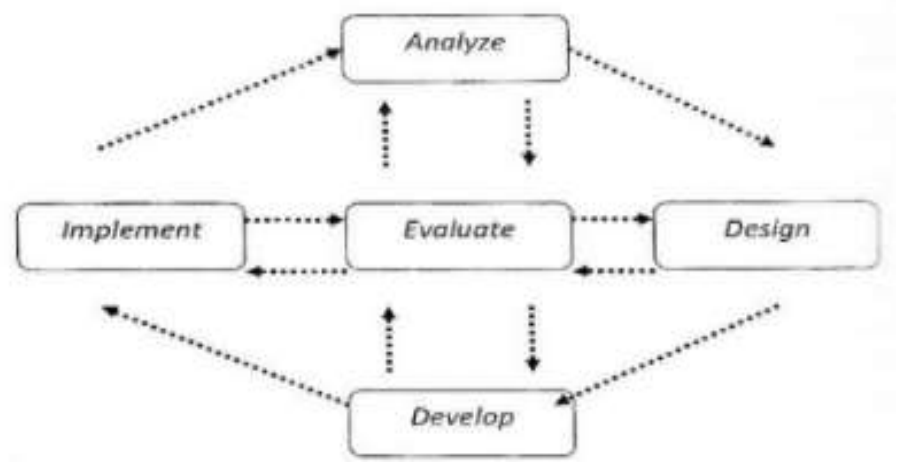

Gambar 1. Bagan ADDIE

Penelitian ini dilaksanakan di SDN Menteng 03, Jakarta Pusat. Langkah pertama yang dilakukan peneliti adalah menganalisis kebutuhan pada tempat penelitian melalui kegiatan observasi proses pembelajaran dan wawancara dengan guru kelas. Setelah menganalisis, peneliti merancang media yang akan dikembangkan dengan menentukan materi yang akan dimuat dalam produk, serta merancang alur dan layout produk. Setelah produk dirancang oleh peneliti, produk pun dikembangkan dengan menerjemahkan spesifikasi desain ke dalam bentuk fisik yang menghasilkan prototype produk yang dikembangkan. Setelah produk dikembangkan sesuai dengan konsep, produk akan diimplementasikan pada subjek penelitian. Penelitian pengembangan ini melibatkan dosen ahli media, dosen ahli materi IPA, dan dosen ahli bahasa untuk melakukan validasi produk, setelah produk dinyatakan valid, produk pun diimplementasikan pada subjek penelitian, yaitu peserta didik kelas IV SDN Menteng 03 untuk mendapat penilaian dari segi kemanfaatan dan kemudahan penggunaan produk dengan menggunakan kuisioner. Tahap akhir pada penelitian ini adalah evaluasi. Tahap evaluasi ini berupa evaluasi formatif. Fungsi evaluasi formatif berfokus mengungkapkan kekurangan suatu produk selama proses perkembangan dengan tujuan menghasilkan saran dalam proses peningkatannya (Rudhito, 2019: 36). Evaluasi formatif pada penelitian ini dilakukan dengan tiga tahap, yaitu uji coba ahli (expert review), evaluasi satu lawan satu (one to one evaluation), dan evaluasi kelompok kecil (small group evaluation) untuk meninjau kelayakan dari produk yang dikembangkan.

Teknik yang digunakan untuk analisis data yang digunakan dalam penelitian ini adalah statistik deskriptif kuantitatif. Statistik deskriptif digunakan untuk menganalisis data yang telah terkumpul sebagaimana adanya tanpa bermaksud membuat kesimpulan yang berlaku untuk umum atau generalisasi (Siyoto, 2015: 90). Perhitungan ini menggunakan statistik sederhana berupa kuisioner dengan skala 1-4 untuk kuisioner para ahli dengan rincian 1 sangat kurang baik, 2 kurang baik, 3 baik, dan 4 sangat baik. Adapun angket untuk peserta didik menggunakan skala Guttman dengan rentang 0 sampai 1 dengan rincian skala 0 tidak dan 1 ya. Setelah data diperoleh, peneliti melakukan perhitungan dengan rumus sebagai berikut:

$$
\frac{\text { Jumlah skor Hasil Pengumpulan Data }}{\text { Jumlah Butir Soal } \times \text { Skala Point Terting gi Soal }} \times 100
$$

Dalam menafsirkan data kuantitatif menjadi data kualitatif berdasarkan kriteria yang diperoleh, peneliti menggunakan acuan yaitu (Riduwan \& Sunarto, 2013: 78): 


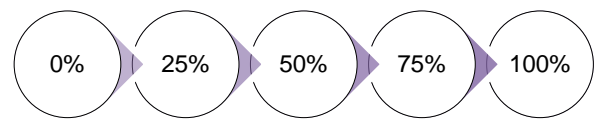

\section{Gambar 2. Garis Rentang Skor Kriteria}

Rentang skor kriteria diperoleh dengan cara membagi presentasi tertinggi dengan jumlah kriteria pilihan sehingga diperoleh deskripsi hasil pengumpulan data kuantitaif menjadi kualitatif sebagai berikut:

$0 \%-25 \%$ : Sangat Kurang Baik

$26 \%-50 \%$ : Kurang Baik

$51 \%-75 \% \quad$ : Baik

$76 \%-100 \%$ : Sangat Baik

\section{HASIL DAN PEMBAHASAN}

Hasil observasi pembelajaran dan wawancara guru kelas pada tahap analisis menunjukkan bahwa peserta didik membutuhkan sebuah inovasi media pembelajaran yang lebih menarik perhatian peserta didik dalam pembelajaran, khususnya pada materi IPA di kelas IV sekolah dasar. Inovasi media pembelajaran yang dilakukan peneliti adalah mengembangkan poster interaktif berbasis android. Setelah menganalisis kebutuhan kemudian peneliti merancang produk yang akan dikembangkan. Hasil perancangan produk adalah materi yang akan dimuat dalam produk yaitu muatan pelajaran IPA tentang pentingnya upaya pelestarian dan keseimbangan sumber daya alam. Peneliti pun mengembangkan poster interaktif dengan animasi dan fitur interaktif menjadi media pembelajaran berbasis android dengan format aplikasi (.apk). Poster ini dikembangkan dengan ukuran yang fleksibel sehingga ukuran layar aplikasi poster akan menyesuaikan layar android penggunanya.

Penelitian ini menghasilkan poster interaktif berbasis android dengan 3 komponen utama, yaitu desain latar belakang, fitur interaktif berupa tombol-tombol, dan pemograman. Poster ini terdiri dari 5 halaman yang terdiri dari halaman poster, halaman KD dan tujuan pembelajaran, halaman video, halaman petunjuk kuis dan halaman kuis. Berikut adalah tampilan layar dari poster interaktif yang dikembangkan.

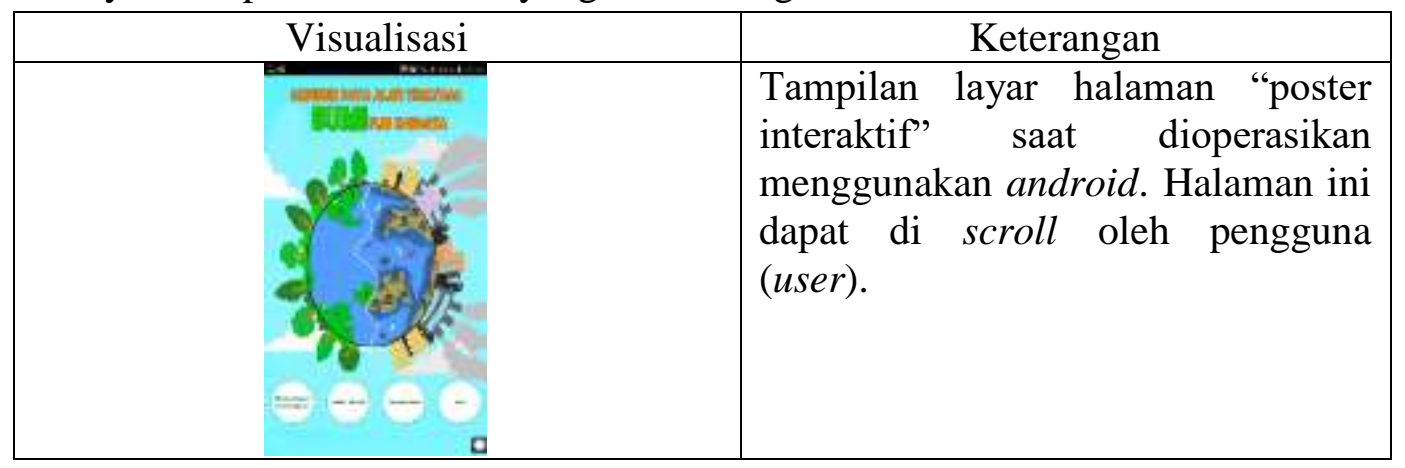




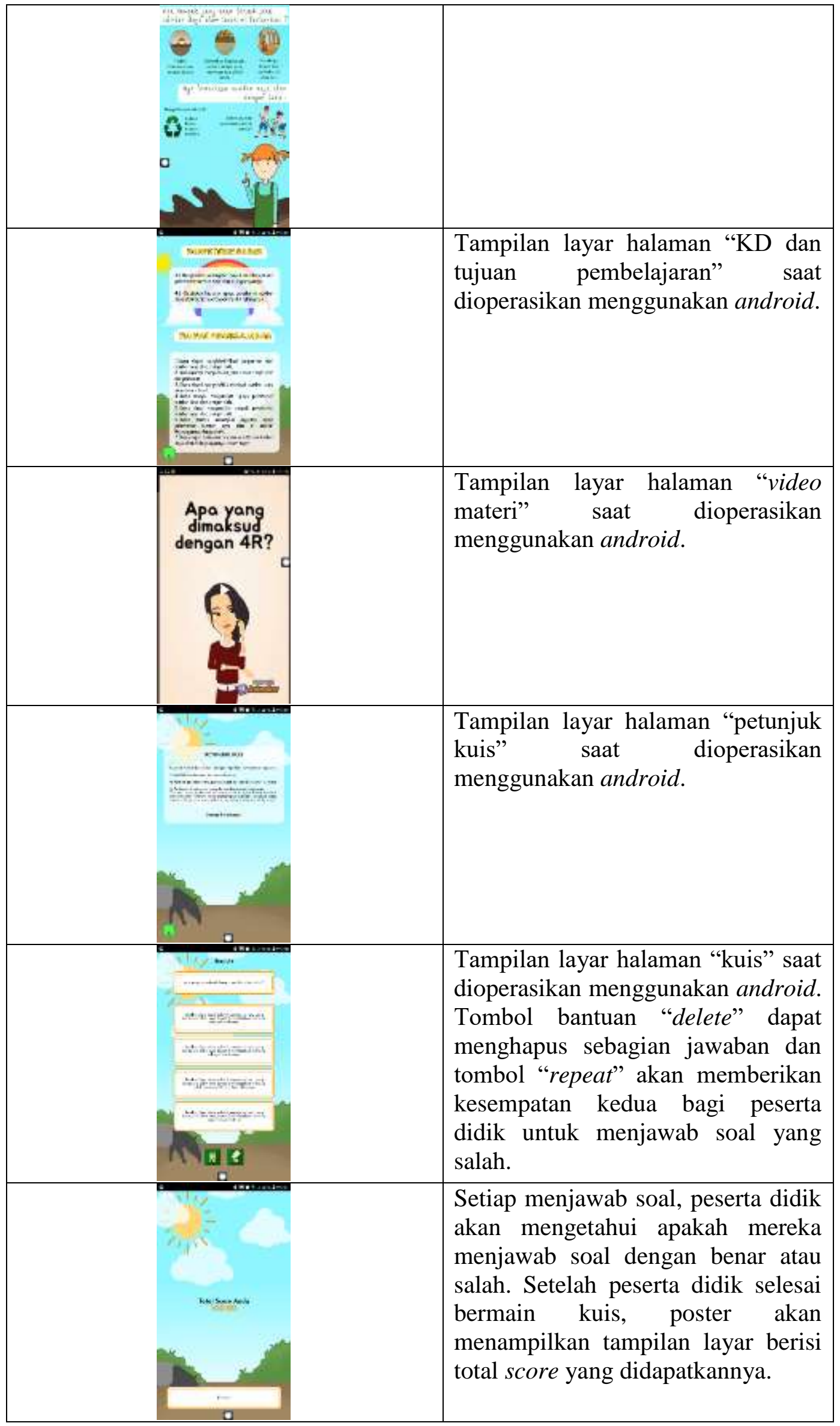


Setelah produk dikembangkan peneliti pun mengimplementasikan poster interaktif berbasis android pada peserta didik. Sebelum diimplementasikan pada peserta didik, produk ini terlebih dahulu diujicoba dan divalidasi oleh ahli (expert review).

\section{Uji coba produk oleh Ahli Media}

Instrumen kuisioner untuk ahli media terdiri dari 25 butir yang terdiri dari aspek kelayakan penyajian, multimedia, dan perangkat lunak. Skor maksimum dari kuisioner ahli media adalah 100. Berikut hasil uji coba dan validasi dari ahli media:

Tabel 1. Hasil Validasi Ahli Media

\begin{tabular}{|c|c|c|}
\hline Indikator Penilaian & Butir Penilaian & Skor \\
\hline \multirow{9}{*}{ A. Desain } & 1. Desain latar belakang. & 4 \\
\hline & 2. Daya tarik latar belakang. & 4 \\
\hline & $\begin{array}{lll}\text { 3. Kejelasan gambar dan } \\
\text { animasi. }\end{array}$ & 4 \\
\hline & $\begin{array}{l}\text { 4. Daya tarik gambar dan } \\
\text { animasi. }\end{array}$ & 4 \\
\hline & $\begin{array}{l}\text { 5. Kesesuaian gambar dan } \\
\text { animasi yang digunakan. }\end{array}$ & 4 \\
\hline & 6. Ketepatan tata letak. & 4 \\
\hline & 7. Daya tarik warna. & 4 \\
\hline & $\begin{array}{l}\text { 8. Kesesuaian warna dengan } \\
\text { karakteristik peserta didik. }\end{array}$ & 4 \\
\hline & $\begin{array}{l}\text { 9. Ketepatan penggunaan ikon } \\
\text { dan simbol. }\end{array}$ & 4 \\
\hline \multirow[t]{5}{*}{ B. Tipografi } & 10. Kejelasan huruf. & 4 \\
\hline & 11. Kesesuaian ukuran huruf. & 4 \\
\hline & 12. Kesesuaian jenis huruf. & 4 \\
\hline & 13. Kesesuaian ukuran spasi. & 4 \\
\hline & 14. Variasi ukuran. & 4 \\
\hline \multirow[t]{3}{*}{ C. Penggunaan Audio } & 15. Daya tarik audio. & 3 \\
\hline & 16. Variasi audio. & 3 \\
\hline & $\begin{array}{l}\text { 17. Kesesuaian audio dengan } \\
\text { karakteristik peserta didik. }\end{array}$ & 4 \\
\hline \multirow[t]{3}{*}{ D. Video Materi } & 18. Daya tarik animasi. & 4 \\
\hline & $\begin{array}{l}\text { 19. Ketepatan gambar, } \\
\text { simbol, dan animasi } \\
\text { digunakan. }\end{array}$ & 4 \\
\hline & $\begin{array}{l}\text { 20. Kejelasan suara dan musik } \\
\text { pengiring. }\end{array}$ & 3 \\
\hline \multirow[t]{4}{*}{ E. Program } & $\begin{array}{l}\text { 21. Kemudahan install dan } \\
\text { uninstall. }\end{array}$ & 4 \\
\hline & 22. Ukuran file poster interaktif. & 4 \\
\hline & $\begin{array}{l}\text { 23. Kemudahan pengoperasian } \\
\text { fungsi tombol. }\end{array}$ & 4 \\
\hline & 24. Konsistensi fungsi tombol. & 4 \\
\hline
\end{tabular}




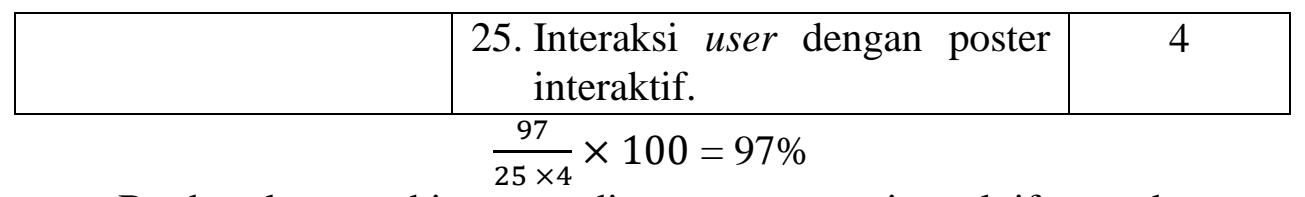

Berdasarkan perhitungan di atas, poster interaktif mendapat persentase penilaian sebesar 97\% artinya "Sangat Baik" dan dinyatakan layak untuk diujicobakan dengan revisi sesuai saran. Adapun revisi yang dilakukan oleh peneliti terhadap saran dari ahli media adalah sebagai berikut.

a. Meningkatkan kualitas dan volume suara pada video materi dengan melakukan editing volume audio penjelasan menjadi lebih besar dengan volume backsound yang lebih kecil..

b. Merubah halaman menu utama menjadi halaman yang langsung menampilkan poster.

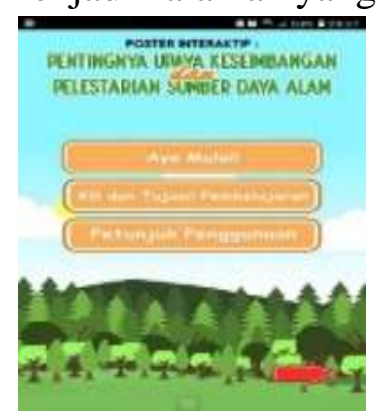

Gambar 3. Halaman Utama Poster Interaktif sebelum Diperbaiki

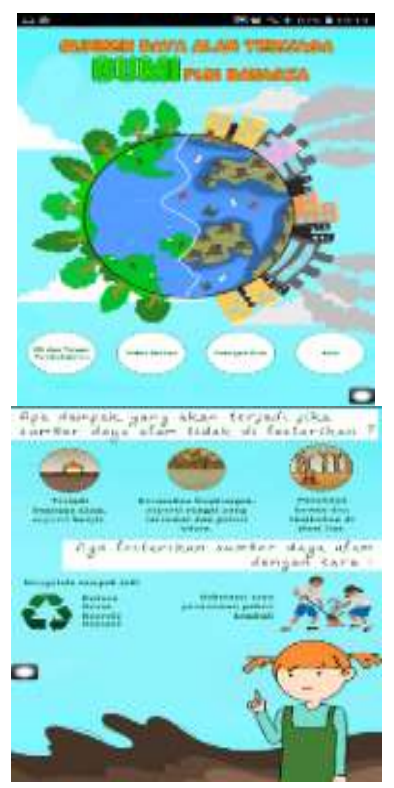

Gambar 4. Halaman Utama Poster Intraktif setelah Diperbaiki

\section{Uji coba produk oleh Ahli Materi}

Tabel 2. Hasil Validasi Ahli Materi

\begin{tabular}{|l|l|c|}
\hline Indikator Penilaian & \multicolumn{1}{|c|}{ Butir Penilaian } & Skor \\
\hline A. Kesesuaian Materi & 1. Kelengkapan materi. & 4 \\
\cline { 2 - 3 } $\begin{array}{l}\text { Dengan Kompetensi } \\
\text { Dasar (KD) dan }\end{array}$ 2. Keluasan materi. & 3 \\
\cline { 2 - 3 } Tujuan Pembelajaran & 3. Kedalaman materi. & 3 \\
\hline
\end{tabular}




\begin{tabular}{|c|c|c|}
\hline \multirow[t]{4}{*}{ B. Keakuratan Materi } & $\begin{array}{l}\text { 4. } \begin{array}{l}\text { Keakuratan } \\
\text { definisi. }\end{array} \\
\text { konsep }\end{array}$ & 4 \\
\hline & 5. Keakuratan contoh. & 4 \\
\hline & $\begin{array}{ll}\text { 6. } & \text { Keakuratan } \\
\text { ilustrasi. } & \text { gambar dan }\end{array}$ & 4 \\
\hline & 7. Keakuratan soal. & 4 \\
\hline \multirow[t]{3}{*}{ C. Kemutakhiran Materi } & $\begin{array}{l}\text { 8. Kesesuaian materi dengan } \\
\text { perkembangan ilmu. }\end{array}$ & 3 \\
\hline & $\begin{array}{l}\text { 9. Contoh sesuai dengan } \\
\text { kehidupan sehari-hari. }\end{array}$ & 3 \\
\hline & $\begin{array}{l}\text { 10. Gambar dan animasi seperti } \\
\text { dalam kehidupan sehari-hari. }\end{array}$ & 3 \\
\hline \multirow[t]{2}{*}{$\begin{array}{l}\text { D. Kualitas Penjelasan } \\
\text { Konsep Materi }\end{array}$} & $\begin{array}{l}\text { 11. Kemudahan peserta didik } \\
\text { dalam memahami materi } \\
\text { pembelajaran. }\end{array}$ & 4 \\
\hline & $\begin{array}{l}\text { 12. Kesesuaian uraian materi } \\
\text { dengan tingkat berpikir } \\
\text { peserta didik. }\end{array}$ & 4 \\
\hline \multirow[t]{3}{*}{ E. Tampilan Materi } & 13. Kemenarikan materi. & 4 \\
\hline & $\begin{array}{l}\text { 14. Ketepatan animasi dengan } \\
\text { materi. }\end{array}$ & 4 \\
\hline & $\begin{array}{l}\text { 15. Kesesuaian audio dengan } \\
\text { materi. }\end{array}$ & 4 \\
\hline
\end{tabular}

Berdasarkan perhitungan di atas, poster interaktif mendapat persentase penilaian sebesar 91,66\% artinya "Sangat Baik" dan dinyatakan layak untuk diujicobakan dengan revisi sesuai saran. Adapun revisi yang dilakukan oleh peneliti terhadap saran dari ahli materi adalah menambahkan contoh konkret bagaimana cara melestarikan sumber daya alam pada video materi dan menambahkan materi singkat pada desain poster.

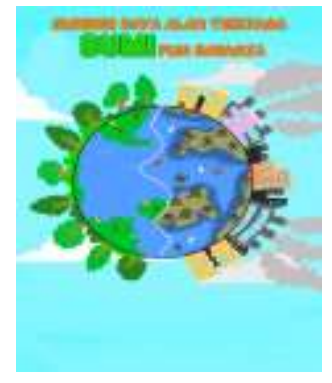

\section{Gambar 5. Desain Poster sebelum Diperbaiki}

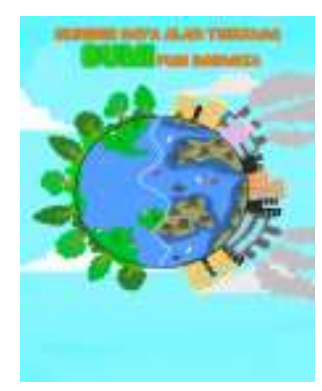




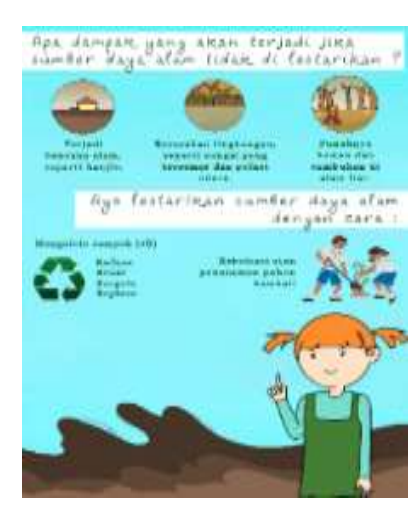

\section{Gambar 6. Desain Poster setelah Diperbaiki}

\section{Uji coba produk oleh Ahli Bahasa}

Tabel 3. Hasil Validasi Ahli Bahasa

\begin{tabular}{|c|c|c|}
\hline Indikator Penilaian & Butir Penilaian & Skor \\
\hline \multirow[t]{4}{*}{ A. Kelayakan Bahasa } & \begin{tabular}{|llr} 
1. & Kesesuaian & dengan \\
& karakteristik peserta didik \\
& kelas IV SD. & \\
\end{tabular} & 4 \\
\hline & 2. Bahasa mudah dipahami. & 4 \\
\hline & 3. Keefektifan kalimat. & 4 \\
\hline & 4. Komunikatif. & 4 \\
\hline \multirow[t]{6}{*}{ B. Tipografi } & 5. Kejelasan huruf. & 4 \\
\hline & 6. Kesesuaian jenis huruf. & 3 \\
\hline & 7. Variasi jenis huruf & 3 \\
\hline & 8. Variasi ukuran huruf. & 3 \\
\hline & 9. Variasi warna huruf. & 4 \\
\hline & 10. Kesesuaian ukuran spasi. & 3 \\
\hline
\end{tabular}

Berdasarkan perhitungan di atas, poster interaktif mendapat persentase penilaian sebesar 90\% artinya Sangat Baik dan dinyatakan layak untuk diujicobakan tanpa revisi. Berikut adalah hasil rekapitulasi terhadap poster interaktif berbasis android:

Tabel 4. Hasil Rekapitulasi Validasi Ahli

\begin{tabular}{|c|c|c|c|c|c|}
\hline No. & Responden & $\begin{array}{c}\text { Jumlah } \\
\text { Butir }\end{array}$ & $\begin{array}{c}\text { Skor } \\
\text { Maksimum }\end{array}$ & $\begin{array}{c}\text { Skor yang } \\
\text { Didapat }\end{array}$ & $\begin{array}{c}\text { Persentase } \\
\text { Penilaian }\end{array}$ \\
\hline 1. & Ahli Media & 25 & 100 & 97 & $97 \%$ \\
\hline 2. & Ahli Materi & 15 & 60 & 55 & $91,66 \%$ \\
\hline 3. & Ahli Bahasa & 10 & 40 & 36 & $90 \%$ \\
\hline \multicolumn{5}{|c|}{ Rata-Rata Persentase Penilaian } \\
\hline
\end{tabular}

Berdasarkan hasil rekapitulasi penilaian dari uji coba dan validasi ahli (expert review), poster interaktif berbasis android mendapat rata-rata persentase penilaian sebesar $92,88 \%$. Data kuantitatif dari rata-rata persentase penilaian ahli kemudian ditafsirkan menjadi data kualitatif sehingga dapat dikatakan bahwa poster interaktif berbasis android memeroleh 
kriteria "Sangat Baik" dan dapat diujicoba kepada peserta didik untuk mengetahui minat dan daya tarik peserta didik terhadap poster yang dikembangkan.

\section{Uji coba satu lawan satu (One to One Evaluation)}

Pada tahap ini, uji coba melibatkan tiga orang peserta didik kelas IV A SDN Menteng 03. Hasil uji coba one to one adalah sebagai berikut:

Tabel 5. Hasil Uji Coba One to One

\begin{tabular}{|c|c|c|c|}
\hline No. & Nama Peserta Didik & Jumlah & Persentase (\%) \\
\hline 1. & HAS & 20 & $100 \%$ \\
\hline 2. & IA & 20 & $100 \%$ \\
\hline 3. & MWA & 20 & $100 \%$ \\
\hline \multicolumn{2}{|c|}{ Rata-Rata Persentase } \\
\hline
\end{tabular}

\section{Uji coba Small Group}

Pada tahap ini, uji coba melibatkan tiga orang peserta didik kelas IV A SDN Menteng 03. Hasil uji coba one to one adalah sebagai berikut:

Tabel 6. Hasil Uji Coba Small Group

\begin{tabular}{|c|c|c|c|}
\hline No. & Nama Peserta Didik & Jumlah & Persentase (\%) \\
\hline 1. & FK & 20 & $100 \%$ \\
\hline 2. & KAA & 19 & $95 \%$ \\
\hline 3. & LNZ & 18 & $90 \%$ \\
\hline 4. & MDJA & 20 & $100 \%$ \\
\hline 5. & RP & 20 & $100 \%$ \\
\hline 6. & SNW & 20 & $100 \%$ \\
\hline \multicolumn{3}{|c|}{ Rata-Rata Persentase } \\
\hline
\end{tabular}

Penilaian peserta didik terdiri dari 20 butir pernyataan dalam menilai kelayakan dan kemenarikan poster interaktif berbasis android. Berdasarkan rata-rata persentase dari hasil uji coba one to one dan uji coba small group, poster interaktif dapat dideskripsikan dalam kategori "Sangat Baik" karena berada dalam rentang 76\% - 100\%. Pengembangan poster menjadi media pembelajaran yang interaktif sudah pernah dilakukan pada penelitian sebelumnya. Salah satu peneliti yang mengembangkan poster interaktif adalah Raudah Kusuma Firdani dan Retno Tri Hariastuti. Peneliti tersebut mengembangkan poster menjadi poster interaktif berbasis website. Bentuk interaksi antara poster dengan peserta didik sebagai pengguna yaitu saat peserta didik melakukan kegiatan scan barcode untuk ke halaman website berisi informasi lebih lanjut terkait materi yang sedang dibahas dalam poster (Kusuma Firdani \& Tri Hariastuti, 2019: 109).

Melihat perkembangan alat yang digunakan saat ini, penelitian ini pun mengembangkan poster interaktif menjadi berbasis android. Hal ini dilakukan peneliti agar peserta didik dapat lebih mudah mengakses poster dimanapun dan kapanpun. Adapun pengembangan yang dilakukan peneliti yaitu dengan memberikan fitur interaktif berupa tombol-tombol yang dapat digunakan oleh peserta didik. Interaksi peserta didik dengan poster ini pun terjadi saat peserta menekan tombol jawaban dari setiap pertanyaan di fitur kuis. Peserta didik akan mendapatkan reinforcement positif jika dapat menjawab pertanyaan dengan benar dan reinforcement negatif jika jawaban yang diberikan belum tepat. Melalui 
poster interaktif ini, peserta didik dapat mengakses materi dari tulisan, animasi, dan video, serta bermain kuis hanya melalui ponsel android.

Produk yang dikembangkan oleh peneliti memiliki beberapa kelebihan, yaitu: 1) mudah digunakan karena poster ini berbasis android sehingga dapat diakses dimanapun dan kapanpun; 2) penggunaan bahasa yang sederhana dan mudah dipahai pada poster sudah disesuaikan dengan tingkat perkembangan bahasa peserta didik; 3) desain gambar dan animasi pada poster menggunakan warna cerah dan sudah disesuaikan dengan materi yang dipelajari sehingga dapat meningkatkan daya tarik dan pemahaman peserta didik; dan 4) poster interaktif berbasis android lebih efektif dibandingkan dengan poster biasa karena peserta didik dapat memahami materi dari mengamati gambar hingga menyimak video, dan mengerjakan kuis untuk mengetahui tingkat pemahamannya hanya dengan satu aplikasi.

Seluruh tahap pada penelitian ini sudah dilakukan dengan baik untuk menghasilkan produk yang bermanfaat dan berkualitas, namun peneliti menyadari adanya kekurangan produk karena keterbatasan dalam penelitian. Adapun keterbatasan yang dihadapi oleh penelitian dan pengembangan ini yaitu sebagai berikut:

1. Keterbatasan Subjek Pengguna dan Ruang Lingkup

Ruang lingkup dalam penelitian pengembangan ini hanya terbatas pada lingkup kecil yang terdiri dari sembilan peserta didik kelas IV SD. Jika penelitian dan pengembangan ini dilakukan dalam ruang lingkup besar dengan melibatkan seluruh peserta didik kelas IV di SDN Menteng 03 atau beberapa sekolah lainnya, peneliti tentu memerlukan waktu yang cukup lama. Maka dari itu, poster interaktif ini memerlukan pengembangan lebih dalam sehingga dapat digunakan pada sekolah dasar secara umum.

2. Keterbatasan Cara Instalasi dan Pengoperasian Produk

Produk yang dikembangkan merupakan media berbasis android sehingga memerlukan instalasi terlebih dahulu. Produk yang dikembangkan memerlukan cara yang cukup panjang untuk instalasi dan masih memerlukan koneksi internet yang stabil untuk mengoperasikan produk. Maka dari itu, pengembangan produk ini masih perlu dilakukan dengan mengunggah aplikasi poster di Play store sehingga lebih mudah untuk digunakan.

3. Keterbatasan Interaksi Produk dengan Pengguna

Produk yang dikembangkan belum melibatkan peserta didik dalam kegiatan belajar karena bentuk interaksi hanya terbatas pada saat peserta didik menekan tombol-tombol untuk berpindah halaman saja. Poster interaktif pun hanya memberikan feedback saat peserta didik bermain kuis. Oleh karena itu, produk ini masih memerlukan pengembangan dalam interaksinya. Peneliti selanjutnya dapat menambahkan berbagai kegiatan menarik yang dapat meningkatkan aktivitas peserta didik

\section{PENUTUP}

Penelitian ini menghasilkan sebuah produk berupa poster interaktif berbasis android pada muatan IPA di kelas IV sekolah dasar. Berdasarkan hasil penelitian, peneliti dapat menarik kesimpulan bahwa poster interaktif sangat layak digunakan. Hal ini berdasarkan rata-rata persentase penilaian dari ahli media, ahli materi, dan ahli bahasa sebesar $92,88 \%$ sehingga produk ini mendapat kategori "Sangat Baik". Poster interaktif berbasis android pun dapat meningkatkan daya tarik peserta didik dalam aktivitas belajar. Hal ini dapat disimpulkan berdasarkan hasil penilaian uji coba one to one dan uji coba small group pada 
peserta didik kelas IV di SDN Menteng 03. Hasil uji coba menunjukkan bahwa produk ini sangat baik dengan rata-rata persentase uji coba one to one sebesar $100 \%$ dan rata-rata persentase uji coba small group sebesar 97,5\%. Berdasarkan hasil penilaian para ahli dan hasil uji coba pada peserta didik, poster interaktif berbasis android yang dikembangkan oleh peneliti layak untuk digunakan sebagai media pembelajaran yang lebih menarik dalam pembelajaran IPA, khususnya tentang materi "Pentingnya Upaya Pelestarian dan Keseimbangan Sumber Daya Alam” di kelas IV SD.

\section{UCAPAN TERIMA KASIH}

Penelitian ini dapat terselesaikan dengan baik karena melibatkan banyak orang yang membantu. Maka dari itu, peneliti menyampaikan ucapan terima kasih kepada seluruh pihak yang sudah membantu peneliti melakukan penelitian baik secara moril maupun materil. Secara khusus, peneliti menyampaikan ucapan terima kasih kepada kedua orang tua yang sudah mendo'akan dan mendukung penelitian ini. Selanjutnya peneliti mengucapkan terima kasih kepada dosen pembimbing, yaitu Ibu Tunjungsari Sekaringtyas, M.Pd dan Ibu Uswatun Hasanah, M.Pd yang sudah membimbing dan mengarahkan peneliti, serta para dosen ahli yang sudah bersedia secara sukarela melakukan uji coba dan validasi produk yang dikembangkan oleh peneliti. Peneliti mengucapkan terima kasih kepada Kepala Sekolah dan Guru di SDN Menteng 03, Jakarta Pusat yang telah mengizinkan peneliti melakukan penelitian, serta peserta didik kelas IV A yang bersedia menjadi subjek penelitian. Terakhir, peneliti ingin menyampaikan terima kasih untuk Program Studi Pendidikan Fisika, Fakultas Keguruan dan Ilmu Pendidikan Universitas Flores, khususnya kepada bapak Melkyanus B. U. Kaleka, S,Pd., M.Pd yang sudah banyak membantu saat menyusun jurnal ini. Semoga kebaikan dan kemudahan yang diberikan dapat menjadi amal baik yang terus mengalir sebagai ilmu yang bermanfaat, aamiin.

\section{DAFTAR PUSTAKA}

Aspahani, E. L., Nugraha, A., \& Giyartini, R. (2020). Rancangan Media E-Poster Berbasis Website Pada Pembelajaran IPA di Sekolah Dasar. Pedadidaktika: Jurnal Ilmiah Pendidikan Guru Sekolah Dasar, 7(2), 158-167.

Budiarta, I. W. (2016). Pengembangan Multimedia Interaktif Model ADDIE untuk Meningkatkan Motivasi Belajar Sejarah Siswa Kelas X-1 Semester Genap di SMAN 1 Sukasada, Buleleng, Bali. Widya Winayata: Jurnal Pendidikan Sejarah, 4(1).

Dale, V. H., \& Kline, K. L. (2017). Interactive posters: A valuable means of enhancing communication and learning about productive paths toward sustainable bioenergy. Biofuels, Bioproducts and Biorefining, 11(2), 243-246.

Dewi, M. P., \& Kristin, F. (2017). Meningkatkan Hasil Belajar Ipa Melalui Metode Inquiry Pada Siswa Kelas V SD. Mimbar Sekolah Dasar, 4(1), 67-78.

Herlina, \& KH, M. (2019). Pemrograman Aplikasi Android dengan Android Studio, Photoshop, dan Audition. Elex Media Komputindo.

Kusuma Firdani, R., \& Tri Hariastuti, R. (2019). Pengembangan Media Poster Interaktif Bimbingan Dan Konseling Karier Berbasis Website Untuk Informasi Studi Lanjut Di Kelas IX Smp Negeri 3 Kota Mojokerto. Jurnal BK UNESA, 9(3), 105-110.

Mendikbud. (2020). Mendikbud Terbitkan SE tentang Pelaksanaan Pendidikan dalam Masa Darurat Covid-19. https://www.kemdikbud.go.id/main/blog/2020/03/mendikbudterbitkan-se-tentang-pelaksanaan-pendidikan-dalam-masa-darurat-covid19

Paramitha, A. P. (2018). Pengembangan Media Poster pada Pembelajaran IPA Materi Ciri- 
Ciri Lingkungan Sehat dan Lingkungan Tidak Sehat Siswa Kelas III SDN Lirboyo 2 Tahun Pelajaran 2017/2018. Simki-Pedagogia, 2(5), 123-154.

Pribadi, B. A. (2017). Media \& Teknologi dalam Pembelajaran. Kencana.

Rayanto, Y. H., \& Sugianti. (2020). Penelitian Pengembangan Model ADDIE dan R2D2: Teori dan Praktek. Lembaga Academic \& Research Institute.

Riduwan, \& Sunarto. (2013). Pengantar Statistik untuk Penelitian Pendidikan, Sosial, Ekonomi, Komunikasi, dan Bisnis. Alfabeta.

Riyanto, S., \& Hatmawan, A. A. (2020). Metode Riset Penelitian Kuantitatif Penelitian di Bidang Manajemen, Teknik, Pendidikan, dan Eksperimen. Deepublish Publisher.

Rudhito, M. A. (2019). Dasar-Dasar Penelitian Desain untuk Pendidikan. Deepublish Publisher.

Sinta, L. (2016). Penggunaan Media Interaktif pada Pembelajaran Konsep Usaha dan Energi di MTsS Ulumul Quran Banda Aceh. Universitas Islam Negeri Ar-Raniry.

Siyoto, S. (2015). Dasar Metodologi Penelitian. Literasi Media Publishing.

Sugiyono. (2018). Metode Penelitian Kuantitatif, Kualitatif, dan R\&D. Alfabeta.

Sulthon. (2016). Pembelajaran IPA yang Efektif dan Menyenangkan bagi Siswa MI. ELEMENTARY: Islamic Teacher Journal, 4(1), 38-54.

Tahel, F., \& Ginting, E. (2019). Perancangan Aplikasi Media Pembelajaran Pengenalan Pahlawan Nasional untuk Meningkatkan Rasa Nasionalis Berbasis Android. Teknomatika, 09(02), 113-120.

Widjayanti, W. R., Masfingatin, T., \& Setyansah, R. K. (2018). Media Pembelajaran Interaktif Berbasis Animasi Pada Materi Statistika Untuk Siswa Kelas 7 Smp. Jurnal Pendidikan Matematika, 13(1), 101-112. 